\title{
Artelogie
}

Recherche sur les arts, le patrimoine et la littérature de I'Amérique latine

16 | 2021

Fotografía y migraciones, siglos XIX-XXI.

\section{Grete Stern and Gisèle Freund: Two Photographic Modernities in Argentine Exile}

\section{Clara Masnatta}

\section{OpenEdition}

\section{Journals}

Electronic version

URL: https://journals.openedition.org/artelogie/9242

DOI: $10.4000 /$ artelogie.9242

ISSN: 2115-6395

\section{Publisher}

Association ESCAL

Electronic reference

Clara Masnatta, "Grete Stern and Gisèle Freund: Two Photographic Modernities in Argentine Exile", Artelogie [Online], 16 | 2021, Online since 27 January 2021, connection on 03 September 2021. URL: http://journals.openedition.org/artelogie/9242 ; DOl: https://doi.org/10.4000/artelogie.9242

This text was automatically generated on 3 September 2021

Association ESCAL 


\title{
Grete Stern and Gisèle Freund: Two Photographic Modernities in Argentine Exile
}

\author{
Clara Masnatta
}

1 A portrait photographer is never alone. Every portrait is an encounter. The encounter sets the stage, the players interpret one another, they act, the fantasy of an identity is recorded. The portrait is this theater. Critics have dismissed this dialog to put the photographer at center stage, seeking chiefly to repress co-authorships, even sometimes sneering at the sitter's pose-which, in film, we would call "acting"-in face of the heroic portraitist's performance.

2 Not alone in portraits-on which her fame is almost unfounded-but throughout her career, Grete Stern persistently appeared in duos. Both in her Berlin years and after her relocation to Buenos Aires, Grete appeared in partnership with uncommon frequency. Duos are central in the photographic arc stretching from Walter Peterhans, her teacher at the Bauhaus, to Etelvina "Cacho" del Carmen Alaniz, her maid and personal assistant in Buenos Aires. Grete and Ellen Auerbach as the professional tandem ringl + pit, Grete and Horacio Coppola as the avant-garde couple, and finally, the twosome Grete and Gisèle Freund, make up Stern's stereo landscape.

Except for the last two, these pairs involved collaborations that have all been critically explored. The lacuna around the two Jewish-German photographers who took the Porteño intellectual field unawares during the Second World War is astonishing. This essay addresses the lacuna head-on by focusing on the portraits each produced, and advances the manque relationship between Grete Stern and Gisèle Freund as a springboard to an expanded modernist visual culture.

4 If such a scholarly gap is astounding, the concrete dissociation between Grete and Gisèle-their missed encounter-is mind-boggling. How was it possible for the paths of peers in both origin and destination, fellows in forfeiting potential lives in order to make photography their own, not to cross? How was it possible for two women who, each varyingly against norms, joined up with another woman for love or work, to 
remain disconnected? It is almost incomprehensible that, indebted as they both were to Victoria Ocampo for their local debuts, Gisèle Freund, from her landing in Buenos Aires in 1941 to her Paris repaysement in 1946, never once ran into Grete Stern. Neither did they meet on Gisèle's return visits in 1947 or 1949. That not a trace of even mutual curiosity survives is unfathomable.

The disjunction between Stern and Freund recurs less speculatively in the specific innovations each introduced into Argentina's photography field: Grete the technique of photomontage; Gisèle color film, of which she was a pioneer. Collage and color are two photographic modernities that coexisted almost without mingling. Until, that is, they stopped being novel and started touching timidly, or also colliding with their changing ideological contrails.

6 The Dadaist practice that would become famous as collage around 1916, with John Heartfield at the forefront, predates the term "photomontage" by almost a decade. The practice can in fact be traced back to the nineteenth century, claims Olivier Lugon, when assembling separate portraits in a single image was in fashion. ${ }^{1}$ But the modernity of photomontage-the experience, as Moholy-Nagy put it, of "Simultaneous seeing by means of transparent superimposition"-would become manifest when the association it stirred turned into one of the eight forms of "photographic vision" that the Bauhaus theorist defined in his 1925 book malerei, fotografie, film [Painting, Photography, Film].

7 Historically, color photography too has existed since the nineteenth century. Various processes and techniques preceded the birth of modern color photography in its 35millimeter film form, launched in October $1936 .{ }^{2}$ Stern referred to one of these glassplate processes in a page of her neatly-typed class notes (today preserved in the Bauhaus-Archiv). Namely, the Silbereosin to be immersed in a bath of one part pinacryptol to 5,000 parts water-a autocromo remote cousin of the brothers Augustedistant cousin of the autochrome invented by the Lumière brothers. Freund, who had no schooling but was self-taught, took up color photography after moving to Paris, when 35-millimeter slide film was commercially available in the Kodachrome and Agfacolor versions. Gisèle chose Agfacolor for her firsts ventures in color in 1938, then did her Argentine portraits in Kodachrome. Her grounds for switching from the German to the American slide film appear to be random or practical, rather than strictly aesthetic or political.

8 Although the American company Eastman Kodak beat Agfacolor-Neu in the film race by over a year, in 1935, negative-positive film from the German Agfa was first past the post in 1939. Unlike slide film, which required projection, this technology enabled images to be printed on color paper. In then Nazi Germany, the production monopoly and use of the medium were subsumed under the needs of total warfare, and the medium's distribution dictated by the Machiavellian Propaganda Minister, Joseph Goebbels. Afgacolor's patent would eventually come to be part of the spoils seized and distributed within Europe- a modern war trophy.

9 The disjunction between color and collage in photography was due to a late, politically complex marriage of photographic paper and color. Color photographers spin another twist to the story by grace of being-with a few exceptions-amateurs. In face of the monochrome hermit of the darkroom, modern color was collective in its early production and reception. Be it as slides or, later, as paper photographs, authorized laboratories were in charge of developing color images. It was 1946 before Ektrachrome 
film enabled users to develop them themselves widely. ${ }^{3}$ Yet Gisèle chose to go on leaving things up to the lab and also favoring projections throughout her career. Gisèle arrived to Buenos Aires with a printed sample of her color work, an album now lost, the press reports. Even before color sensitive paper became available, color prints were done using the carbro process or the painstaking dye transfer.

De gustibus et coloribus non est disputandum. Given that color is the most relative medium in art, we cannot assert that color and photomontage are polar opposites, nor that photomontage operates a surgical intervention in the naturalistic body of the photo, a naturalism which color would come to reinforce. Color was, as a matter of fact, variously perceived throughout the twentieth century, as artificial or, paradoxically, as allegorical or literal, or, quite simply, as novel, in the cases that Lisa Hostetler examined for the American context. ${ }^{4}$ Indeed, the composition of fragments in photomontage was first considered to be a return to realism in the writings of Franz Roh. ${ }^{5}$ Perhaps one could imagine color and collage combined in the United States as summa of the country's modernity: Photomontage, which would translate the disassemblage of modern American life and Fordism, would express itself effectively in the technical innovation of Kodak color. But such an assumption is false. On the contrary, both color and photomontage were held back as modernist signifiers in face of the "straight photography" that Paul Strand popularized in America, as Sally Stein studied. ${ }^{6}$ Color, in combination with certain visibility of found materials that is proper to photomontage, may have found a global exception in British photographer Madame Yevonde (Yevonde Cumbers Middleton, 1893-1975). 'Yevonde's imagination conveyed both æsthetics in Vivex-a photographic process from the 1930s that also used glassplate negatives. D. A. Spencer invented the color printing on cellophane of the attractive Vivex process, which was marketed by Color Photography Ltd. of Willesden and remained an UK-exclusive product. The onset of the Second World War brought about its discontinuation and ended the archipelago of such fantasies.

11 Both Grete and Gisèle spent lengthy spells in London at the time when Madame Yevonde was active. Yevonde had a remarkable and long career as a portrait photographer and occasional lecturer. There is even some speculation that MoholyNagy attended one of her lectures. ${ }^{8}$ But to imagine that Grete and Gisèle somehow approached Yevonde's work (Grete during her exile in London from 1933 to 1935, Gisèle while carrying out photographic commissions in 1939) would be to maximize the scale of their missed encounter, their rendez vous raté. ${ }^{9}$

Grete and Gisèle, a disparate pair, a disconnected pair. But why a pair? Before history was written and established Grete Stern for her photomontage series, Dreams, and Gisèle Freund for her portrait portfolio (a unique color record of canonical twentiethcentury writers and artists), the emergent Argentine photo-criticism yoked Grete and Gisèle together as two wrongs that did not make a right. Investing them with misogyny and vituperation (passions that run deep in tango), the Porteño publication Correo Fotográfico Sudamericano reviewed Grete's first solo exhibition in 1943 identifying at once a forerunner: Gisèle's 1942 show. ${ }^{10}$ Unlike critics to come, who preferred silence to marking their ignorance, reviewer Mariano Enrique Hernando linked the portraits exhibited by Grete and Gisèle for their "absurd criteria" with the slanderer's sureness. ${ }^{11}$ "Go visit Müller's place,' I was told by the director 'and see what one gets when trying to be original without knowing the fundamentals of photography." 

intellectual stars-which included James Joyce, Frida Kahlo, Jorge Luis Borges, Virginia Woolf, Walter Benjamin, André Malraux-Freund focused on the rise of the bourgeois photoportrait to author the first doctoral study on the history of photography..$^{12}$ The portrait was fundamental in Freund's career. For Grete, it would be just another genre, not dominant, just one among many. The fabrication that is proper to photomontagethe visibility, even if transparent, of the assembly-bleeds and thrives in Grete's portraits. Let us anticipate: Grete's monochrome modernity is witty and pop, at times, camp; Gisèle's color modernity is prosaic, rather, kitsch. Emotions get instilled in the mass-produced, second-hand can be authentic. question. Grete's card is a printed photo and an example of graphic design. A female photoportrait confronts us as the dot over the " $\mathrm{i}$ " in the word "invitation" in this composition of cardboard cut-outs, drawing on paper, and fabric scraps, in which the face appears crowned with artificial laurels; below it, the word "photos" embossed with yarn appends, almost loose. The multitextured whole inscribes a simple sentence across the many fragments of varying size and typography: "Invitation to see Grete Stern's photos June 10th through 25th, Müller Gallery, 946 Florida Street." A playful composition like this is light-years away from the sober cardboard inviting the reader with standard typography to the "Exhibition of Color Photographs by Gisèle Freund Dr.ès-lettres of the University of Paris."

Bypassing all differences, the Correo Fotográfico reviewer had no compunction about equating, confusing, and misnaming them. Gisèle opened her exhibition a few meters away and a few months before Grete's, viz., on September 2, 1942, at Amigos del Arte, 659 Florida Street. Such metonymic proximity implodes with derision into a delicious review:

Greta Stern is a second part of Gisèle Freud and if Gisèle Freud delivered to us the most negative set of portraits in the history of exhibitions, the reader may deduce what this second part constituted by Greta Stern will be like. Both two ladies, with absurd criteria of photography, consider that the art in their portraits is not provided by the quality of the work, but by the name of the person reproduced. [sic]( Mariano Enrique Hernando, $1943: 16)^{13}$

16

The name's importance is symptomatic: while misnaming the portraitists, the prominence of the sitters' names is attacked. But such lapsus calami harbor more than irony. A woman can only stand before the lens like an actress, not behind it as a photographer-read this between the lines. If an echo of Garbo resonates in "Greta", the sobriquet "la Gisèle" [sic] imparts sheer cruelty to familial monikering, and spite appears quite unequivocally in "la Freud."

17 For the women of the Weimar Republic in the 1920s and 1930s, photography represented emancipation. Ute Eskilsden put it accurately: Photography brought about the possibility of earning a living and the "chance to participate" in the public sphere. Photographing, in a way, supplemented the hard-won suffrage. A "New Woman" was born alongside the "New Objectivity" geometry. But here, in 1943, the so-called "New Woman" of Weimar faced long-standing male chauvinism in the Argentine Republic. In 1918 , the same year in which female suffrage was established in Germany, a woman sought lodge at the Plaza Hotel in Buenos Aires, the American artist and patron Katherine Dreier. But unaccompanied by her husband, a woman alone - not even in 
the company of her father or brother- could not sojourn at this five-star establishement, touted South American's most modern and finest hotel, as Drier retold in her book, Five Months in the Argentine from a Woman's Point of View, 1918 to $1919 .{ }^{14}$

18 A first step against misogyny-dominant to this day-was taken in 1947 when the women's vote was made law in Argentina. Argentina was three decades behind Germany in obtaining the women's vote that was enforced in half of Europe in the 1910's. The motion was neither so far-advanced for Latin America: Brazil and Uruguay granted the vote to women in 1932, Cuba in 1934. Remember that Guillermo de Torre, who served as art critic in the journal Sur, in 1931 referred to women "not inclined to intellectual matters in abstracto" as making up the majority of the audience in lectures. 15

19 Lectures and talks abounded in great number and quality around those years in Buenos Aires. Lecturing cultural travelers (Le Corbusier, Fillippo Marinetti, Luigi Pirandello, Waldo Franck, Albert Einstein, to name a few) who passed through the city made, in the words of Ramón Gómez de la Serna, "Buenos Aires an intellectual hub de tout premier plan", one that egregious visiting lecturer Ortega y Gasset compared to Pericles's Athens. ${ }^{16}$ It was precisely at one of such lectures that Gisèle's portraits were first presented (Gisèle in absentia) to the Porteño public by the director of Sur, Victoria Ocampo, in 1939. ${ }^{17}$

20 Culture grows symbolic roots, in turn, making names important. Who is photographed, how they are photographed, and where and how those photos circulate make up a portrait. Names-recorded, malgré lui, by the reviewer ${ }^{18}$-are important because they reveal the different pantheons that each photographer constructed. Neither Freund nor Stern were commercial portrait photographers strictly speaking; they chose who to photograph. This does not mean that they did not take commissions from outside their circle of preference, nor that they did not charge the favored sitters within. Proof is the business card advertising the services of each. ${ }^{19}$ Gisèle's Parisian card listed small fortunes; 2,000 francs per portrait and a further 500 per copy. The "Grete Stern Portraits" card was more sparing with details; it just bore a telephone number. But we know that, for one portrait, a sum equivalent to a month's rent for a centrally located two-room apartment came to swell Grete's coffers. ${ }^{20}$ Gisèle charged two months of a worker's salary for a portrait with copy in 1939. Contact sheets show that both were in the habit of taking three or four shots per sitter.

21 Leica-armed Gisèle preferred to shoot in the sitter's own space, reporter-style: to photograph the artist at home or against the designated bookcase backdrop. Like the studio portraitist she was, Grete would "take no chance shots." She controlled backgrounds and lighting for her scenes' composition with a sternness that included props. Grete used a slower, medium or large format camera-a Yashica 6x6 or a Linhof 9x12-which called for longer sitting times. Such decelerated rhetoric of the pose was conjugated with the grammar of the New Objectivity, and produced portraits of limited circulation. At the antipodes of Gisèle, an expert in the portrait's social life and iconization.

If, for our Correo Fotográfico reviewer, names were almost superfluous, the portrait of Moni Hermelo "lacks the numbers to be a perfect ID card" [sic]. It was the frontality of this neutrally-lit close-up that would make Grete's photo "ID card perfect." Norms then in vogue in Buenos Aires demanded some light and shadow play. "If the artistic failure is little short of absolute," claimed Mr. Hernando, "the technical quality is every bit as 
poor." And he added that the portraits displayed "washed faces, plastered hairdos, and the utter absence of modeling for want of any sense of lighting." Without shadows evincing volume, the image is flattened. The devoluminizing effect brings out the background; grounds stand out prominently. At the same time, the at once salient portrait's geometry catches the eye: A Cubist halo of sorts frames Moni's head, her earrings seem two suns in this eye-level shot portrait. We notice the "V" of her neckline, her plaid jacket, the way her figure stands out symmetrically against the background, like a cut-out.

This flattening-which I have called "pop"-is a product of Stern's chosen lighting and background arrangement. It applies to all her portraits, which are mostly three-quarter angle shots, not frontal like the ones of Moni Hermelo (19??) or Clément Moreau (1943), exhibited at the Müller gallery. ${ }^{21}$ This is the angle that best captures the look of a face: captured slightly from the side, the outlines of the nose, and the shape of the forehead, cheeks, and chin all become clearly visible. When not shot at eye level, Grete opted for a low camera angle, sometimes even below chin level, which makes the portrayed seem more powerful. Even if the beholder can almost peep into their nostrils. Yet the closeup leaves the accompanying disproportionate body effect out of the camera's frame.

Grete "has a soft spot for backgrounds," our reviewer points out, and "the Hollywood pose." The fact is that figure and ground generated the scene for "Greta." Backgrounds frequently corroded the gray or neutral orthodoxies of the passport photo. Even in a sober portrait like the one of Henríquez Ureña wearing a hat, from 1942, one can make out the streaked fabric background thanks to the shadows cast by Don Pedro's ears in the lower-bottom. Complex patterns, embroideries, textiles, textured paper, corrugated cardboard, or a simple plant served no other purpose than fracturing realistic continuity. Backgrounds display their imperfections, their hems and edges. They support the figures that rest on their ragged design, both physically (the position of repose suits slower camera times such as Grete's) and conceptually.

The photograph's semiotic engineering lies between figure and ground. It is rehearsed. Three shots make up the 1945 portrait series of Diyi Laañ: Grete decided against those with the plant and neutral backgrounds, and went for a rhomboid of floral wallpaper. ${ }^{22}$ On another contact sheet, from 1933, we see corrugated cardboard enveloping Bertolt Brecht visibly held by two hands. The hands would eventually be extirpated from the frame, and the playwright left all nicely wrapped up in impressions to come. Theater often made Grete a verso seamstress ; yet, most of the time, it is the dressmaking, the whole weft and woof, that gets displayed. In 1942, the delicate, sensual dancer Renate Schottelius was portrayed laying bare the seam that forms her wig's parting. Artifice is crafted, and workmanship for display.

26 Years later, in 1949, Grete gave center stage to the backstage of her studio in Ramos Mejía. The set for her portrait of writer Arturo Serrano Plajaa, his head bowed beside a three-spot lamp with exposed wires, included a mirror from her usual battery, placed here against the baseboard. Like the mirror stripped of its function, paraphernalia and set dressing appear ostensibly as props in her portraits, set appurtenances.

Grete went for artifice. Her portraits are installations in portrait disguise. This is the best description for one particular female portrait: the hatted and jeweled woman from 1934, who was immortalized as an entelechy by the name of Stella. It is fitting to adapt Walter Benjamin's über-famous analogy of the surgeon and the cameraman, and name as wounds Grete's graphic sutures, the photomontage stitching that evokes El 
Lissitzky's compositional style. It is also right and proper to dwell a little over all these disguises' embroidery.

In her 1943 "Self-portrait-Composition," Grete staged the dictum that a still life is the author's self-portrait. Self-presentations, whichever the medium or genre, are exceptional sites for exploring female identity and sexuality. Gisèle abstained from portraying herself in color; she wrote colorful memoirs instead. Grete's self-portrait conjugated her face reflected in a mirror with the elements of the graphic and photographic trade-her set squares, thumbtacks, and lenses. Presentation appears together with its compositional means. This self-portrait is a small æsthetic treatise, as synthetic (for brevity and artificiality) as the aforementioned invitation card that bore her signature. On the card, a sketched hand pointed its index finger to the inscription "to see." Also inscribed (in less vertical or straightforward a manner) was a philosophy of photography distancing itself from the ontology that makes photos say "This has been" or "This is like this." Deixis multiplied by manipulation always says "Look at this" in Grete's images.

While the self-portrait falters in unison with the still life, figure and background fuse in a fugue. The dynamics of difference and repetition are the engine. Lenses and set squares begin the game of the double. Grete's oval face, framed by the round mirror, echoes the shell; the shadows of the thumbtacks reiterate the leaves' nervures. Plastic foliage crowns this composition; on stepping back, a face sketched by reflected light emerges. The leaves, which would recur over the years as part of a stable cast of props, frame it like hair; the set square further as headdress.

With this self-portrait, the photographer added an other femininity to the repertoire of female stereotypes which ringl + pit began to take apart in the 1930s. Such dismantling, to be specific, sprang from photographing gloves, corset, tulles, veils, and silks as proxies for the grande dame, the housewife, the dancer, the fiancée, or the femme fatale. ${ }^{23}$ For Alejandra Uslenghi, this image marked a new Argentine beginning, after which Stern should veer toward volumes. ${ }^{24}$ This is the turn that the 1928 issue of bauhaus magazine (no. 24) showcased with Hebert Bayer's front cover. Photography here went from representing objects as flattened structures to emphasizing textural depths within the surface, as T'ai Smith noted. ${ }^{25}$ The 1927 issue appeared folded in the 1928 front cover - as to tuck away the previous bauhaus magazine photo-dynamics. Bayer here deployed the graphic design process as still life with an interplay of shadows and volumes - a very different play than the back illumination that turned criminals into saints, and was so dear to the reigning taste in Buenos Aires. This same interplay was akin to the one Grete and Coppola presented in the "Composition for a Book of Various Types," also of 1943.

31 In the absence of transforming encounters, Grete's visual grammar proves rather constant across years and genres. A grammar as steady as the battery of resources, which she dosed out with an iconoclastic dropper. Inevitably, contexts do their work and resignify shades of meanings. The New Objectivity produced graphic studies of texture and geometry for sure innovative. That æsthetic and political coalescence successfully managed to blurred the distinction between art and commerce, between avant-garde and masses. Its fancy for textures and fabrics lived on in Grete with unforeseen consequences. It is graphic in Grete's Chaco photos from the 1960s. This series produced a new form of ethnography - a crossbreeding of crafts catalog with making-of together with reportage and a kind of photographs that were not exactly 
portraits because, as Ignacio Aguiló pointed out, they recorded types with generic labels. According to Aguiló, proper names distinguished the sitters reproduced as well as portraits of ethnographic photos. This last kind effectively dominated in the series. ${ }^{26}$ Toward the end of her life, Grete stated her ongoing interest in the constructedness of all things, and opposed the artifice that she sought (also regarding landscape, i.e., the natural par excellence) to the "natural" that color should convey:

"Regarding landscapes, I am interested in showing how it is constructed. Other people want to show the different colors. I did not have the elements of color - only black and white and grey. I think of this one of the purposes of this kind of photography is to preserve and show the natural."( Cordula Frowein: 25. Okt-29. Nov. 1988) ${ }^{27}$

There was no visual turn; still, 1943 was a key year for Grete. She ended her marriage with Horacio Coppola; their joint work Cómo se imprime un libro [How to Print a Book] was published by Imprenta López (including the letterpress photo mentioned earlier among the book's images). Another solo exhibition at Sagitario Gallery followed after the one at Müller. The short-lived, and left-inclined journal Libertad Creadora published an article on Stern featuring three full-page reproductions of Stern's photo-portraits (all authors of the magazine) and a portrait of Grete herself sketched by Clément Moreau $^{28}$. In the press, Correo Literario published a short piece article praising Stern's photography, in particular, her self-portrait, "for its resources, for its tonality, for its future", ${ }^{29}$ appeared. ${ }^{30}$ The article in Correo Literario also reproduced three portraits: one frontal, of "the painter [sic] Clément Moreau" with a his pipe,(a frontal shot), "the painter Atilio Rossi" (19??), and "Mary Stewart" (1943), named sans métier - these two, profile shots. Yet the press printing quality made it impossible for one to appreciate tone or background nuances; a problem that persisted in pieces featured in La Nación and even in the higher quality reproduction of the subtle shadow Henriquez Ureña portrait. Only a remarkable composition or a famous name would have saved the newsprint paper portraits from oblivion.

Grete's portraits failed in matters of reproduction and distribution. Portraits, in this regard, stand in contrast to the work Jodi Roberts studied in such exemplary fashion. ${ }^{31}$ Conversely, Gisèle's genius lay in the circulation and popularization of her images. Time Magazine featured Gisèle's color portrait of James Joyce reading with a magnifying glass on the cover of the May 8, 1939 issue. It announced Finnegan's Wake, Joyce's most experimental novel, or, really, the century's. Grete indeed worked extensively in advertising, but not with the portrait genre. She certainly never produced a cover shot of such importance-- a fact that perhaps should spare us some disenchantment. The portrait of the woman who changed our way of looking at a face is disappointment: The photo of Maria Falconetti (1944), who starred in the film of most radical close-ups, Carl Theodor Dreyer's Joan of Arc (1928), begs for a another realism - without costume. Even if the flashiest billboard displayed her name, the profile of la Falconetti would remain unrecognizable in the belle époque dress and chapeau de paille d'Italie.

Moreover, formal analysis applies rather limitedly to Freund's photos; they bear no correlation with Stern's morphology. For Gisèle, there were sumptuous dispositions, and those eager to display their own effigy. André Gide posed under Leopardi's death mask as the latest reincarnation of the eminence. Jean Cocteau appeared mesmeric beneath an exotic red wooden hand or by an exquisite art nouveau lamp. Except for choreographies of this kind, it is futile to engage in firm formal calculations. However, 
a few aspects recur in Freund's depiction of intellectuals. Portraits often feature the head and hands as the thinking and writing elements of the writer's trade; the head often tilted, the hands often connected with the chin, forehead, or cheek. In contrast to Grete's low angle shots that achieve certain magnifying for the subject, Gisèle's point of view begs no reverence as it is sometimes from slightly above the head. While Stern's treatment variation included profile and rear shots of sitters, these have no occurrence in Freund's portraits sessions.

Norah Borges (a painter, and sister of famous writer Jorge Luis) as alternatively done by Freund and Stern can serve for comparison. Grete Stern shows Norah in quasi-profile, three-quarters view that profits from Norah's own square neck dress to frame her head between the pattern on the linen and the delicate texturing of a few grey hairs. Gisèle Freund shot Norah roughly three years before Stern; with tilted head, with her cheek resting on her hand, from an oblique view that is recognizably Freund's, as are the eyes the portrait's protagonist (with the usual pupils' spot shining back with the portraits' light).

Freund's semiotic engineering lay in the portrait's frame, to wit, the extraphotographic process of iconization of her portraits. Her frame was made of language, words written or declaimed in the slide's projection. Whether unkempt or neatly posed, Freund's portraits opened the door to a relation, that is, to an acquaintance and a narration that made the photo at once unique and repeatable. Gisèle broadcasted myths; her practice was complicit in the power of the icon; photography was an auratic medium. Gisèle's modernity was nostalgic, with an eye on the past.

Grete exposed the plot; Gisèle fabulated. Grete unmasked realism; Gisèle masked illusion as illustrious. We go back to our beginning comparison with a question that should come first: What is a portrait? The reviewer who paired our photographers defined it through a moral imperative: "The portrait should reflect the sitter's personality." A paradox emerges: Formulaic portraits must reveal personalities. "Greta", Hernando protested, did not know how to interpret Mario Bravo's personality nor Atilio Cóppola's, looking here like a radio drama beau. Pose-induced subjectivity was not factored in the sitter's visibility. Just as sitter and photographer make the portrait, staging and posing are the (here overlooked) portrait's dialectics. Neglect recurs. A similar formula was couched in "The Facial Nudes of Grete Stern"- this was the title of the review by María Elena Walsh appearing in Sur some years later. Grete's "soul-baring" portraits were shown in The Writer's House SADE in 1952. This time around, the exhibition featured exclusively writers' portraits of Argentina alone; including one of Walsh herself at age 22 .

Indeed, the pantheon that Grete came to espouse was of Argentine artists. In London, she took mainly portraits of exiled Germans: Bertolt Brecht, Helene Weigel, Karl Korsch, Paula Heimann. But Grete's affiliation soon became apparent. Right before her last portrait retrospective (from her early days in 1927 right up to 1972), Grete traveled to Paris and photographed Argentine artists and writers who had taken up residence there. This trip also marked her first return to Germany since her forced departure in 1933. Yet she returned from Germany without capturing that old republic.

Grete's portrait portfolio is incomparable in magnitude or international scope to Gisèle's. Just a handful of luminaries in common (Brecht, Weigel, Borges, Neruda, Henríquez Ureña) appeared shared between Grete's around one hundred and Gisèle's over three hundred personalities drawn with light. Nor did Grete's critical fortune as 
portrait photographer- add Manuel Mujica Láinez's 1952 La Nación write-up-rise above the occasions mentioned. Photoportraits followed the norms of physiognomy in these examples. Age-old Lavaterian science got a prompt update through nineteenthcentury alchemy in these reviews.

Another cliché of photographic criticism, unforeseen by Lavater, was the one that Freund personally cultivated to exploit her garden world of literati: Intimacy between portraitist and sitter thickened physiognomic complexity.

41 "To be 'done' by Grete Stern amounts to being captured as the fullest expression of yourself, being yourself too much," wrote María Elena Walsh. ${ }^{32}$ Against the sitter's subjective performance, as antidote to the self-conscious staging of an identity, Grete qua ringl + pit launched the sleepers.

Capturing someone asleep sought to diminish the performance at stake in the portrait. To begin with, this strategy was part of the compendium that Grete's contemporaries expanded by doing blind portraits, either literally, like Paul Strand's blind woman, or by using a hidden camera, such as Walker Evans did in the subway. ${ }^{33}$ What is more, closed-eye portraits are plastic. Repose desubjectivizes the subject; the living turn painterly as if by magic. The intimacy between portraitist and sitter that springs from witnessing a dream turns the dreamer into, if not an object, a prey for gaze. What Benjamin theorized in the aura origami gets betrayed: It is the gaze returned that makes an image human. Gisele's portrait of Victoria Ocampo looking at us is fiercely human in all her alarming beauty; it is the image rather of a predator than a prey's.

43 The series of heads at rest on textured pillows proliferated in Grete's work in the 1930s. A resting Ellen Auerbach from 1928, or Ellen with Walter Auerbach, or the "Study of a Bald Head for a Portrait" (both from 1930) are all examples. We can trace a line from this last image all the way up to Grete's last portrait, included in her also last show at the National Fine Arts Museum in Buenos Aires in the spring of 1972. Yet the specular feature of "Study of a Bald Head" was no longer mirror -made -like in "Two Heads" (1972). In this image, the head doubled up as a concave plaster head exposing its negative space. We see it here for the first time and, forty-one years later, as Grete's body double in the last self-portrait that she took. The plaster head prop is uncanny, yet altogether more familiar when not shot from behind- an angle Grete equally chose for photographing her daughter Silvia Cóppola in 1946, or for "Goggi" in 1929.

Consider now that head from egg is one step away. Not the circle but the egg was perfect or, rather, the most favored of the New Objectivity as an object insofar as the egg allowed to focus on photographic possibilities, and fully experiment with light. Egg was also a favorite because it produced a more photogenic lather than shampoo. "The Egg of Columbus" and "Seifenlauge/Soapy Water" of 1930 by ringl + pit had the still life and the moving life in common.

For all their proper names, these photos are more installations than portraits. The head is a thing explored. "New Cosification", with its capitalist undertones, may in fact be more appropriate than objectivity for this chapter of photographic history. All doubts on ovoid objectivity were dispelled by the time "“'Study of a Bald Head"' was reproduced in the design magazine Campo Gráfico (1937) (featuring also Grete' s cover design with a large aerial view of Buenos Aires). This objectivity equally seeped through the portraits of Brecht, Weigel, or Auerbach that came before. The portrait's dialectics 
of staging and posing are restored in these pictures taken in London, and rhyme as well as Engels and Marx.

So, what is a portrait? When the photographic blizzard took the life of images by storm (to paraphrase Siegfried Kracauer), it blew the portrait's definition sky high. The link between word and image (which the early Barthes termed anchorage) took on specific gravity thereafter. Recall that Walter Peterhans labeled a gloves and frock assemblage "Portrait of a Gentleman" (1932). Alfred Stieglitz was more radical, and titled the photo of a cloud "Portrait of Georgia No. 3" (1923).

Gisèle, for her part, put words to work for the most traditional iconophilia; she anchored her close-ups of revered figures with eloquence. Gisèle reinforced the aura and personality that emanated from her portraits with a performance of language. Each portrait was presented with a story that painted the man in the picture with colorful anecdotes, synecdoches of character. The male gender of man here stands: The catalog of women flourishing in the still lifes of ringl + pit was limited in Gisèle's oeuvre. The gender gap went hand in hand with the literary canon represented - a future's long tradition with more kings than queens.

The art of the portrait framed by speech conjured up the magic of the sitter's presence. The portrait's iconization was both subsidiary and contrary to what Walter Benjamin grasped in "The Work of Art in the Age of Technical Reproducibility." Benjamin's much-cited, multi-versioned essay advanced a paradigm shift for art upon its dynamiting by photography. Gisèle's operation was a mixed reaction to this state of the art field; a deceivingly simple question lingered on: Can the sun produce a work of art?

Far from being in its death throes prior to the "photo- inflation," the portrait precipitated a second invention of the photographic medium in the nineteenth century. Characterized by a plethora of innovative reproduction technologies, lighter cameras, faster films, a wave of mass-mediatization, and a torrent of new applications, such as advertising, this revolution (culminating in Disdéri's carte-de-visite in 1854) was the subject of Freund's thesis, La Photographie en France au XIXe siècle (1936). Subsequently expanded and published as Photographie et société (1974), Freund's book was a reference for Roland Barthes in Camera Lucida (1980). The medium's expansion, linked by Freund both to the portrait's democratization and the simultaneous decline in the portrait's art of capturing personality, technically originated in France. But it came to have the greatest implications in the years of the Weimar Republic.

Portraiture played a key role in the debates on modernity when the modern wave swept Germany in the first decades of the twentieth-century. Portrait conventions changed; social types rather than particular individualities came into focus. August Sander embarked on his celebrated atlas of faces, Antlitz der Zeit [Face of Our Time]. A pastrycook, a peasant, a revolutionary, or a bourgeois family - these are some of the trades that Sander recorded in images without their proper names. To be sure, ringl + pit's repertoire extended this catalog of types. In face of such work or also the experiments of Russian Constructivism aiming at more complex subjectivities by way of multiplying the portrait's single image, Gisèle's appeared rather conventional, solidified in the best bourgeois tradition. In the photographic storm, Gisèle distanced herself from avant-garde innovation. Gisèle's were retroportraits done with the latest color technology. Grete's were, let us say, photomounted portraits.

51 In hindsight, Gisèle's career shows that iconization is an effect and the icon a protocol -that is, a form of usage and reading - not the intrinsic attribute of a specific photo. 
Iconic insistence is equally manifest in Grete's most frequently reproduced portraits: Margarita Guerrero, Bertolt Brecht, Horacio Cóppola in a checkered shirt, the woman in a veil, or Walter Peterhans, to name some of her most visible portraits.

Let us go back now to the pantheons that each exhibition on Florida Street presented. Moni Hermelo, Clément Moreau, the painter Lino Eneas Spilimbergo in his atelier, or the less picturesque Cecilia Mossin Kotin-the first woman to obtain a PhD in physics and mathematics in Argentina, and the driving force behind the Balseiro research Institute- were all photographed by Grete. They made up a less glamorous or snob pantheon than Gisèle's gallery of celebrities, composed as it was of the Sur aristocracy of the spirit alongside the aristocratic blood of Mrs. Armour, née Princess Myra Sergeievna Kudashev, who became the wife of US Ambassador Norman Armour after ceasing to be the Imperial Duchess of Russia. The dandy Enrique Larreta, José Ortega y Gasset, Baldomero Fernández Moreno, Adolfo Bioy Casares, an as-yet-uncanonized Jorge Luis Borges all shone from the walls of the Asociación Amigos del Arte. Behind and among them were the colors of Victoria Ocampo.

Gisèle became Sur's (occasional) portraitist, and Victoria her arbiter elegantice. Ocampo informed Freund's pantheon (to her we owe even Gisèle's infamous Virginia Woolf portraits) as well as how the series got presented. It was Victoria Ocampo who livened up the projection of Gisèle's photos with her artful rhetoric at the September 2, 1942. Victoria's dramatic blueprint - the sometime reciter for Stravinsky, life-long lecturer extraordinaire, thoroughly yet unavowedly star-struck Victoria- is indelibly stamped on Gisèle. Combining protocol with performance, Freund's slide-shows travelled the world offering illustrious attraction.

Victoria related more to Gisèle than to Grete or Cóppola's photographic modernity, which she promoted less actively. In Sur's tribute edition to Paul Valéry ${ }^{34}$, Gisèle's (original color) portrait of Valéry appeared reproduced in black-and-white, full-page but uncredited. Gisèle's color portraits were, in truth, transparent for Victoria; they did not contain the photographer's shadow. The omission and her deeper affinity may be explained by a circumstance. When Ocampo visited Alfred Stieglitz's studio in New York in 1930, she retained not Stieglitz's visuals but the words and sensation that described his photography, "It is life itself." It was the magic of color that rendered the life preferred to any formal beauty- like the Perrault fable framing Victoria's visit in "An American Place" suggested. ${ }^{35}$ Victoria's decalage between word and image found an echo in her protégée Gisèle, who for sure combined them masterfully. Freund's career also withheld a misrelation between photographic practice and theoretical discourse.

Is it possible to see an image without words? Looking at Grete's 1937 portrait of Spilimbergo in his atelier crammed with paintings and frames that take up almost the whole visual field, and leave the full-length artist a mere fifth of the picture, observing the sharp contrasts and light tones that give the photograph a graphite on paper cast, and then comparing this with the colors of a handlebar-mustachioed Larreta, the epitome of the dandy, posing on a chair wearing his bishop-like ring, as "la Freud" photographed him in 1942, is made possible by the name's celebrity. Renown may have become rarefied as it reaches today's reader; once a beacon of Argentine letters, Larreta is now almost forgotten.

Homogeneous temporality is a fiction equally outmoded. Variations take shape as much through time's passing as throughout synchrony. Grete was fond of retelling how her house in Ramos Mejía served as meeting point for the Argentine avant-garde, painting 
and dance and literature. Of course not all of it. Different figures and groups did not meet in the city just as diverging æsthetics (be it pictorialism, photomontage, color, or straight photography) existed side by side with their backs turned on one other, the world over.

Buenos Aires was a disjointed cultural field at the time. Unlike interwar Paris, the Argentine capital functioned as a limited contact zone during WWII, and even post-war. Grete and Gisèle's missed encounter is a paragon of such a map. Emblematically, Grete traveled to the north of Argentina to document the life of indigenous peoples; Gisèle to the south, to Patagonia, early on.

History designated Grete and Gisèle as "moderns" with just a few years' difference. In 1965, Grete exhibited the outcome of her travels at the Museum of Modern Art of Buenos Aires; featuring several color photos among the almost two hundred enlargements. "Aborigines of the Gran Chaco" presented indigenous culture with the purpose of enhancing the audience's knowledge and appreciation of the native peoples. It pursued an effect tantamount to the low-angle headshots recurring in the series; namely, ennobling the "folks" or "paisanos" as Grete somewhat endearingly referred to them. ${ }^{36}$ There was nothing spectacular about the didactic slideshow that followed it. Narrated with less artfulness than Gisèle's, the presentations were reportedly tedious. If Grete's "Travelog" ("Relato de viaje"), written in 1971, is anything to go by, they must have been.

In 1968, Gisèle staged a retrospective at the Museum of Modern Art of Paris that looked back on thirty-years of her work as a portraitist. About one hundred fifty color and black-and-white enlargements complemented some ninety color transparencies projected with synchronized audio. The performance was, at this point, automated. By now, Gisèle, who had taken French nationality in 1936, was in every way more Gallic than German. A most successful case of assimilation, Gisèle became the cultural agent of a national identity through her beaming pantheon - one increasingly questioned in a France that repressed numerous conflicts and slowly confronted its colonial and fascist past. Grete, as the Argentine she became officially in 1958, displayed another synthesis, in which the Buenos Aires deliveries remained mostly predicated upon the Bauhaus, and the subject somewhat tacit. Subjects did not occupy Grete's entire syntactic focus and, compared to Gisèle's masterful display of language, they appeared relatively still as per the still life aspect of Grete's portraits. All along counterpoising cultural impulses, from low to high, high to low, spinning the image carousel of each, Grete and Gisèle failed to cross their paths. But they did meet in the end, here in these lines.

\section{NOTES}

1. Olivier Lugon, La Photographie en Allemagne : anthologie de textes 1919-1939, Chambon, Nîmes 1997, p. 211).

2. See Nathalie Boulouch, Le Ciel est bleu: une histoire de la photographie couleur, Paris : Textuel, 2011, (L’Ecriture photographique). See also http://zauberklang.ch/filmcolors/ 
3. A limited first for color film was brought about by Ansco Color Film in the United States.

4. Lisa Hostetler. Color Rush: American Color Photography from Stieglitz to Sherman. Milwaukee Art Museum/Aperture: New York, 2013.

5. Roh, "Eigenausdruck der Natur (Kunst und Fotografie)" in Nach expressionismus. Magischer Realismus. Klinkhardt \& Biermann 1925, pp. 42-48.

6. The black and white æsthetic of American modernism was designed to produce a certain rural nostalgia. Stein also maintains that the resonances of Russian or European constructivism limited the left's implementation of photomontage. Sally Stein, “'Good Fences Make Good Neighbors': American Resistance to Photomontage Between the Wars," in Matthew Teitelbaum (ed.) Montage and Modern Life: 1919-1942, Cambridge, MIT, 1992.

7. Fernand Léger offered an unprecedented black and white photomontage on large streaks color paper, as studied by Matthew Afron "Couleurs dans le monde: Fernand Leger et le photomontage," in: Fernand Leger, Sylvie, Lecoq-Ramond, 2004, Lyon ,Fage, 65-78.

8. Jeannine Fiedler, “A Pioneer of Color Photography: Moholy-Nagy's Camera Works," in Laszlo Moholy-Nagy Color in Transparency Photographic Experiments in Color, 1934-1946, Steidel: 2006, pp 15-24.

9. Grete Stern was certainly familiar with D. A. Spencer's work. Stern was involved in the Argentine edition of Spencer's 1936 book Photography to-day (Oxford U. P., 1936) as the book's cover graphic designer in 1944.(La fotografía al día, Nova, Buenos Aires, 1944).

10. Mariano Enrique Hernando, "La muestra de Grete Stern en los salones Müller." Correo fotográfico sudamericano 22, no. 476, 1943, p.16.

11. To this dubious interpretation we must add David William Foster's, who, when piecing together a lineage for Grete with Alicia D'Amico and Sara Facio, promptly dismissed Gisèle Freund. See David William Foster, Argentine, Mexican, and Guatemalan Photography: Feminist, Queer, and Post-Masculinist Perspective. University of Texas Press, 2014.

12. Gisèle Freund earned her doctorate in Sociology at the Sorbonne in 1936, with her thesis, La photographie en France au dix-neuvième siècle. Essay de sociologie et d'esthétique [Photography in France in the Nineteenth Century: An Essay in Sociology and Æsthetics]. Her dissertation was cited by Louis Aragon, reviewed by Walter Benjamin, and successively rewritten and expanded in the now classic study, Photographie et sociéte [Photography and Society] (1974), cited by Roland Barthes, Susan Sontag, and Pierre Bourdieu.

13. Mariano Enrique Hernando, "Muestra," 1943, p. 16.

14. Katherine Dreier, Five Months in the Argentine from a Woman's Point of View, 1918 to 1919, NY: Fairchild and Sherman, 1920.

15. Guillermo de Torre, "Crítica de Conferencias: Ramón y Morand," Sur 4, Buenos Aires, Spring 1931, 137.

16. Ramón Gómez de la Serna, “Conferencias y conferenciantes”, Explicación de Buenos Aires, Bs As: Ediciones de la Flor, 1975 [1948.], p. 69.

17. See Clara Lucía Masnatta, Freund-schaft: Capturing Aura in an Unframed Literary Exchange. Order No. 3542991, Harvard University. Anne Arbor, 2012, pp. 1-38; 55-63. 
18. Thanks to him we recovered the name of Eve Siegl for Grete Stern's photo, filed in error as "The Irish Painter Stella Steyn" or simply as an anonymous "Female Portrait" in the Folkwang Museum.

19. Grete Stern published ads in the journal Madí advertising her services.

20. Ricardo Piglia in personal correspondence.

21. Clément Moreau was the German printmaker and illustrator Karl Meffert's "nom de guerre". Moreau fled Germany as political exile, first to Switzerland and later to Argentina, where he settled in 1935, and remained actively anti-fascist. He worked as illustrator and educator in exile as well as after his return to Switzerland in 1962. Regarding "Miss Mony Hermelo", she was active in avant-garde circles as early as in 1924, as per an announcement of her reading "poems by Silva Valdés, Arrieta, Juana de Ibarbourou, Hector M. Irusta, Ricardo E. Molinari, Córdova Iturburu, Capdevila among others" in the poetry recital organized by the little magazine Inicial (where Córdova Iturburu, Irusta, and Molinari published) under the aegis of Asociación Amigos del Arte (Inicial, I, no. 7, December 1924).

22. The contacts prints are photocopied in the Museum Folkwang's Grete Stern Archive, in Essen. I am grateful to its Director, Florian Ebner, and to the library's team for their kind disposition.

23. I follow Maud Lavin "ringl + pit: The Representation of Women in German Advertising 1929-33" in: Clean New World: Culture, Politics, and Graphic Design, MIT, 2001; and Jodi Roberts, PhD Dissertation, p. 119.

24. See the essay "Un modernismo migrante" in this volume.

25. T'Ai Smith, "Limits of the Tactile and the Optical: Bauhaus Fabric in the Frame of Photography," Grey Room, no. 25 (Fall, 2006), pp. 6-31.

26. See the essay, "Grete Stern y los Aborígenes del Gran Chaco: continuidades y rupturas en la construcción de una visualidad del indígena chaqueño" in this volume.

27. "An einer Landschaft interessiert mich zu zeigen, wie sie aufgebaut ist. Andere Leute wollen gerne die verschieden Farben zeigen. Die Farbelemente habe ich nicht gehabt- nur Schwarz/Weiss und Grau. Ich denke ein Sinn von dieser Art von Fotografie ist der, das Natürliche zu bewahren und zu zeichen." (My translation, original emphasis, s/p, Cordula Frowein, Emigriert. Grete Stern und Ellen Auerbach Fotografien vor und nach 1933. Stadt Wuppertalm. Unterstützung der Vereinigung der Freunde der Stadbibliothek und der Gothaer Versicherung aus Anlass der Austellung in der Zentralbibliothek (25. Okt-29. Nov. 1988)

28. Lydia Besuchet, "La pintura fotográfica de Grete Stern", Libertad Creadora, vol.1, Ed. Claridad, La Plata, 1943, pp. 224-229.

29.

30. Alberto Denia, "Grete Stern," Correo literario 1, no. 2, Dec. 1, 1943, p. 5.

31. See Jodi Roberts, "Una ciudad en disputa. Fotografías de Buenos Aires de Grete Stern, 1936-1956," in this volume.

32. María Elena Walsh, "Los desnudos faciales de Grete Stern," Sur 215-216, SeptemberOctober 1952, p. 146.

33. See Paul Strand, "Blind," 1916. Image published in the final issue of Camera Work. Walker Evans, "View Down Subway Car with Accordionist Performing in Aisle, New York City," 1938.

34. Sur, no. 126, October 1945. 
35. Ocampo, Victoria, Testimonio. Primera serie, Revista de Occidente, Madrid, 1935, p. 393.

36. Luis Príamo, "Grete Stern y los paisanos del Gran Chaco," in Aborígenes del Gran Chaco. Fotografías de Grete Stern. Colección Matteo Goretti.

\section{ABSTRACTS}

The article examines the divergent photographic modernities, photo-collage and color photography, as practiced by German-Jewish women photographers Grete Stern and Gisèle Freund who, after fleeing Nazi Europe, relocated to Argentina. The analysis is focused on their photo-portraiture.

Le texte examine les deux modernités photographiques divergentes (le photocollage et la photographie couleur) pratiqués en parallèle par Grete Stern Gisèle Freund, femmes photographes d'origine juive allemande qui sont émigrés en Argentine, tous les deux fuyant l'Europe nazie. L'analyse se concentre sur leur photo-portraits.

\section{INDEX}

Palabras claves: exile, color photography, photomontage, women, modernism, Argentina, Bauhaus

Mots-clés: exil, photographie couleur, photomontage, femmes, modernisme, Argentine, Bauhaus.

\section{AUTHOR}

\section{CLARA MASNATTA}

PhD Harvard/Humboldt $U$ of Berlin) is an independent curator, scholar, and author based in Berlin, and born in Buenos Aires. She is the author of Gisèle Freund: Photography on the Stage (Diaphanes, forthcoming) and several book chapters in: "Disassembled Images": Allan Sekula and Contemporary Art, (Leuven U. P., 2019); La cámara como método. La fotografía moderna de Grete Stern y Horacio Coppola (Eterna Cadencia, 2020); About Raymond Williams (Routledge, 2010); and the publication for Rinko Kawauchi's retrospective at the Kunst Haus Wien in 2015. She curated the exhibition Gisèle Freund: Exposición-Espectáculo at the Museo Sívori in Buenos Aires. Masnatta was a Fellow at the ICI Berlin Institute of Cultural Inquiry. 